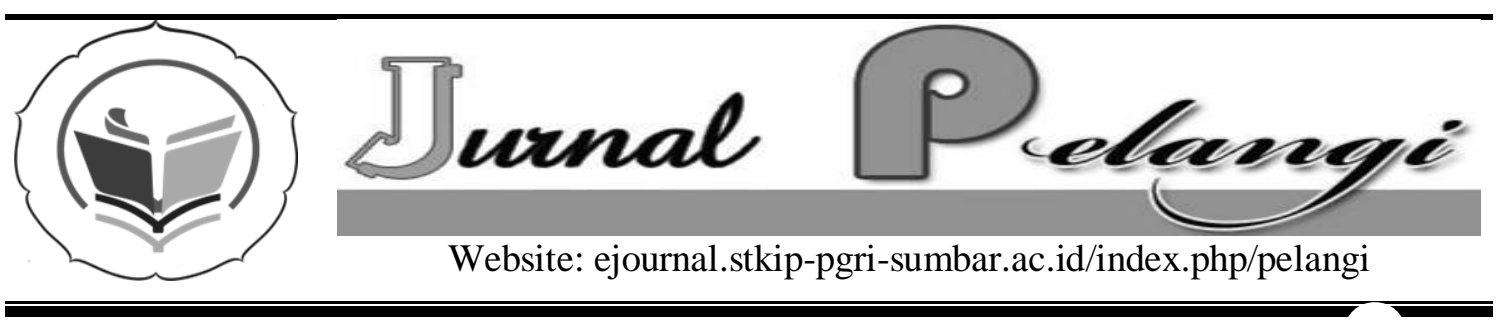

\title{
PENGEMBANGAN MODUL BERBASIS REALISTIK PADA MATERI LINGKARAN UNTUK SISWA KELAS VIII SMP
}

\author{
Hamdunah, Mulia Suryani, Fransisca Isabella Wijaya \\ STKIP PGRI Sumatera Barat \\ hamdunah_nst@yahoo.com
}

\section{INFO ARTIKEL}

\section{Diterima:}

7 Juni 2017

Direview:

9 Juni 2017

Disetujui:

4 September 2017

Kata Kunci:

modul, realistik, lingkaran

\section{Keywords:}

module, realistic, circle

\begin{abstract}
Abstrak
Buku teks belum fasilitasi siswa untuk belajar mandiri serta meningkatkan peran serta siswa dalam belajar, terutama pada materi lingkaran. Permasalahan yang berkaitan dengan lingkaran banyak ditemui dikehidupan sehari-hari siswa, namun materi lingkaran pada buku teks belum dikaitkan dengan keseharian siswa. Mengaitkan materi pelajaran dengan keseharian siswa diharapkan mampu membantu siswa dalam memahami materi lingkaran. Solusi yang ditawarkan dari masalah ini adalah pengembangan modul berbasis realistik untuk materi lingkaran. Penelitian ini merupakan penelitian pengembangan menggunakan rancangan Plomp. Dilakukan 3 tahap, yaitu tahap 1) preliminary research, tahap 2) prototyping phase, dan 3) assessment phase. Metode evaluasi yang digunakan mengacu kepada rancangan evaluasi formatif yang terdiri atas evaluasi diri, tinjauan ahli, evaluasi satu-satu dan evaluasi kelompok kecil. Teknik analisis data yang digunakan adalah deskriptif kuantitatif dan kualitatif. Berdasarkan analisis data disimpulkan bahwa modul yang berbasis realistik yang dikembangkan pada materi lingkaran sudah valid, praktis, dan efektif.
\end{abstract}

Abstract
Textbook had not facilitated the students to study
autonomously and increased the student's role in teaching and
learning on circle material. There were many problems faced
by students on daily activity, yet the circle material on text
book had not been related to the student's daily activity.
Relating the lesson to the student's daily activity is expected to
help the students to comprehend the circle material. The
proposed solution on this problem is realistic-based module
development on circle material. The research was
developmental research from Plomp design where it was


conducted into three stages, 1) preliminary research, 2) prototyping phase, and 3) assessment phase. Evaluation method was formative evaluation consisting self-evaluation, one-to-one evaluation, and small group evaluation. Techniques of data analysis used were quantitative and descriptive qualitative. Based on the data analysis, it can be concluded that the developed module is in very valid criteria. Result of the practical questionnaire both teacher and student shows that module is very practical. Result of the interview both teacher and student shows that module is very practical. Try out test also shows that the module is very practical. It finally states that the realistic-based module is valid, effective and practical on circle material at SMPN 1 Sintuk Toboh Gadang.

\section{PENDAHULUAN}

Matematika adalah salah satu mata pelajaran yang diajarkan pada setiap jenjang pendidikan. Penguasaan matematika sangat dibutuhkan siswa, baik dalam lingkungan sekolah maupun dalam kehidupan seharihari. Oleh karena itu, pembelajaran matematika membekali siswa agar memiliki kemampuan berpikir logis, sistematis, kritis, analitis, kreatif, dan kemampuan kerjasama.

Salah satu materi yang dapat dipelajari oleh siswa agar memiliki kemampuan tersebut yaitu lingkaran. Lingkaran merupakan salah satu materi yang diajarkan pada mata pelajaran matematika di kelas VIII SMP. Lingkaran adalah tempat kedudukan titik-titik yang berjarak sama terhadap satu titik tertentu. Titik tertentu itu adalah titik yang berada tepat di tengah lingkaran yang sering disebut titik pusat lingkaran. Dalam kehidupan sehari-hari sering ditemui permasalahan yang berhubungan dengan lingkaran.

Menurut Hamdani (2011: 120) "Bahan ajar adalah segala bentuk bahan atau materi yang disusun secara sistematis yang digunakan untuk membantu guru atau instruktur dalam melaksanakan kegiatan belajar mengajar sehingga tercipta lingkungan atau suasana yang memungkinkan siswa untuk belajar". Berdasarkan pendapat tersebut dapat disimpulkan bahwa bahan ajar yang dikembangkan harus mempunyai struktur dan urutan yang sistematis, menjelaskan tujuan instruksional yang akan dicapai, sehingga menyediakan bimbingan bagi peserta didik untuk mempelajari bahan tersebut sendiri atau berorientasi pada peserta didik.

Bahan ajar digunakan untuk membantu guru dalam melaksanakan kegiatan belajar mengajar di kelas dalam proses pembelajaran. Sebagaimana menurut Hamdani (2011: 121) penggunaan bahan ajar berfungsi sebagai pedoman bagi guru yang akan mengarahkan semua aktivitasnya dalam proses pembelajaran, sekaligus merupakan substansi kompetensi yang seharusnya diajarkan kepada siswa, sebagai pedoman bagi siswa yang akan mengarahkan semua aktivitasnya dalam proses pembelajaran, sekaligus merupakan substansi kompetensi yang seharusnya dipelajari atau dikuasainya dan sebagai alat evaluasi pencapaian atau penguasaan hasil pembelajaran.

Menurut Hamdani (2011: 219) bahan ajar dapat dikelompokkan menjadi lima, yaitu (1)bahan ajar dalam bentuk cetak, misalnya lembar kerja siswa (LKS), hand out, buku, modul, wilchart, dan lain-lain, (2)bahan ajar berbentuk audio visual, misalnya film, video dan VCD, (3) bahan ajar berbentuk audio, misalnya kaset, radio dan CD audio, (4) visual misalnya foto, gambar, model/maket, (5) multimedia misalnya CD interaktif, computer based learning, internet.

Berdasarkan observasi yang dilakukan pada tanggal 29 Februari - 4 Maret 2016 di SMPN 1 Sintuk Toboh 
Gadang Kabupaten Padang Pariaman, diketahui bahwa guru menggunakan bahan ajar berupa buku teks, banyak kendala yang ditemui dalam proses pembelajaran, seperti buku teks yang digunakan belum bisa menunjang kemandirian siswa dalam belajar, siswa hanya berperan sebagai penerima semua informasi yang disampaikan oleh guru, karena siswa masih kesulitan memahami bahasa yang digunakan dalam buku teks. Siswa kurang aktif karena selama proses pembelajaran siswa tidak menggunakan modul sebagai penunjang aktivitas belajar siswa. Siswa berpendapat matematika merupakan pelajaran yang sulit untuk dipahami. Siswa merasa malas membaca buku dan siswa belum mampu mempelajari materi dengan baik. Berdasarkan uraian di atas, tujuan penelitian ini adalah untuk mengembangkan modul berbasis realistik sebagai media pembelajaran matematika.

\section{METODE PENELITIAN}

Model pengembangan dalam penelitian ini mengikuti model umum desain penelitian menurut Plomp (2013: 19) yang terdiri atas 3 fase yaitu 1) preliminary research, 2) prototyping phase, dan 3) assessment phase. Metode evaluasi formatif yang digunakan adalah evaluasi diri, tinjauan ahli, evaluasi satusatu, uji coba kelompok kecil dan uji coba lapangan. Adapun kriteria evaluasi pada setiap tahap pengembangan terlihat pada Tabel 1.

Tahap investigasi awal (preliminary research) dilakukan proses analisis silabus dan buku teks, dan melakukan wawancara dengan siswa dan guru. Tahap prototipe (prototyping phase) dilakukan proses pembuatan rancangan dan sistematika modul, pembuatan desain modul, memvalidasi, dan uji coba untuk melihat kepraktisan modul. Assessment phase dilakukan uji coba lapangan untuk melihat keefektivitasan modul.

Menurut Depdibud dalam Trianto (2009: 241) "suatu kelas dikatakan tuntas belajarnya (ketuntasan klasikal) jika dalam kelas tersebut $\geq 85 \%$ siswa yang telah tuntas belajarnya". Menurut Suryosobroto (1983: 43) menyatakan bahwa ditinjau dari segi penguasaan modul, yang lebih mementingkan kualitas daripada kuantitas, seorang siswa setelah menguasai paling tidak $75 \%$ dari tujuan dapat diperkenankan pindah ke modul berikutnya.

Tabel 1. Kriteria Evaluasi pada Setiap Tahap Pengembangan

\begin{tabular}{lll}
\hline \multicolumn{1}{c}{ Fase } & \multicolumn{1}{c}{ Kriteria } & \multicolumn{1}{c}{ Deskripsi Aktivitas } \\
\hline $\begin{array}{l}\text { Preliminary } \\
\text { research }\end{array}$ & Penekanan pada validitas isi & $\begin{array}{l}\text { Analisis masalah dan studi } \\
\text { literatur }\end{array}$ \\
\hline $\begin{array}{l}\text { Prototyping } \\
\text { phase }\end{array}$ & $\begin{array}{l}\text { Fokus pada konsisitensi (validitas } \\
\text { konstruk) dan praktikalitas. } \\
\text { Selanjutnya, mengutamakan } \\
\text { praktikalitas dan secara bertahap } \\
\text { menuju efisiensi }\end{array}$ & $\begin{array}{l}\text { Pengembangan prototipe yang } \\
\text { akan diujicoba dan direvisi } \\
\text { berdasarkan evaluasi formatif }\end{array}$ \\
& Praktikalitas dan efisiensi & $\begin{array}{l}\text { Menilai apakah pengguna dapat } \\
\text { menggunakan produk } \\
\text { Assessment } \\
\text { phase }\end{array}$ \\
& & $\begin{array}{l}\text { (praktikalitas) dan berkeinginan } \\
\text { untuk mengaplikasikannya, juga } \\
\text { apakah produk tersebut efektif }\end{array}$ \\
\hline
\end{tabular}


Subjek uji coba dalam penelitian ini adalah dua orang guru matematika dan siswa SMPN 1 Sintuk Toboh Gadang. Jenis data yang digunakan dalam pengembangan modul adalah data kuantitatif dan data kualitatif. Kemudian ditarik kesimpulan dengan teknik deskriptif. Menurut Miles dan Huberman dalam Rohidi (2009:16) analisis kualitatif terdiri dari tiga alur kegiatan yang terjadi secara bersamaan yaitu reduksi data, penyajian data dan penarikan kesimpulan/verifikasi. Instrumen pengumpulan data yang digunakan pada penelitian ini adalah lembar validasi, pedoman wawancara, dan angket, serta soal tes akhir. Data angket diperoleh dengan cara menghitung skor siswa yang menjawab masing-masing item sebagaimana terdapat dalam angket, dengan persentase:

$$
N A=\frac{\text { Jumlah semua skor }}{\text { Skor maksimum }} \times 100
$$

Rerata skor nilai akhir semua siswa dicari dengan menggunakan rumus:

$$
\bar{x}_{N A}=\frac{\sum_{i=1}^{n} N A_{i}}{n} ;(\text { Walpole, 1995: 24) }
$$

Dimana $\bar{x}_{N A}$ adalah rerata hasil skor dari para siswa, $N A_{i}$ adalah nilai akhir skor siswa ke-i dan $n$ adalah banyak siswa.

\section{HASIL DAN PEMBAHASAN}

Pada tahap Preliminary Research (Investigasi Awal) dilakukan analisis silabus, analisis buku teks dan wawancara dengan guru dan siswa. Tahap ini bertujuan untuk mengidentifikasi masalah dan kebutuhan dalam pelaksanaan pembelajaran matematika kelas.

Hasil analisis diperoleh bahwa materi tersebut sesuai dengan standar kompetensi dan kompetensi dasar yang harus dicapai oleh siswa. Urutan materi juga telah sesuai karena materi pertama yaitu unsur dan bagian lingkaran merupakan materi dasar yang harus dipelajari sebelum mempelajari materi selanjutnya.

Hasil analisis buku teks belum sepenuhnya memfasilitasi siswa untuk belajar mandiri dan memudahkan siswa mengkonstruksi konsep matematika dengan baik serta tampilan buku teks kurang menarik serta materi dalam buku masih kurang dikaitkan dengan permasalahan yang terjadi sehari-hari.

Dari hasil wawancara dengan guru matematika, guru menjelaskan bahwa buku teks yang digunakan belum mampu membantu siswa belajar secara mandiri, siswa hanya menyalin materi yang dicatatkan oleh guru di papan tulis, dalam mengerjakan latihan maupun tugas, kebanyakan siswa hanya menunggu jawaban dari temannya, tanpa berinisiatif mengerjakan sendiri. Hasil wawancara yang dilakukan dengan beberapa orang siswa kelas VIII SMPN 1 sintuk Toboh Gadang, diketahui bahwa siswa menganggap bahasa dan isi yang terdapat dalam buku teks sulit dimengerti. Selain itu tampilan bahan ajar yang digunakan tidak menarik. Bahan ajar yang diinginkan siswa adalah bahan ajar yang dapat membantu siswa untuk belajar mandiri dan memiliki tampilan yang menarik serta mudah dipahami dengan cara materi dikaitkan dengan masalah sehari-hari siswa.

Tahap selanjutnya adalah Prototyping Phase (Tahap Pembuatan Prototipe). Modul matematika yang dikembangkan berbasis realistik sehingga modul yang dibuat harus memiliki prinsip utama matematika realistik. Adapun prinsip realistik pada modul sebagai berikut:

a. Didominasi oleh masalah-masalah konteks.

Pembelajaran dimulai dari permasalahan konteks yang terjadi dikehidupan sehari-hari siswa. 
Permasalahn konteks pada modul dapat dilihat pada Gambar 1.
b. Perhatian diberikan
pada pengembangan model-model, situasi, skema dan simbol-simbol.
c. Dari permasalahan konteks yang disajikan kemudian dibuat pemodelan secara matematikanya, seperti yang terlihat pada Gambar 2 .

d. Sumbangan dari para siswa sehingga siswa dapat membuat pembelajaran menjadi konstruktif dan produktif.

e. Interwinning (membuat jalinan) antar topik atau antar pokok bahasan atau antar strand).

Setiap materi pokok bahasan saling berhubungan dan tidak keluar dari kompetensi dasar yang ada.

Selanjutnya kita akan mempelajari unsur-unsur lingkaran. Pada kehidupan sehari-hari sering kita temukan permasalahan yang berhubungan dengan unsur-unsur lingkaran. Untuk memahami apa saja unsur-unsur lingkaran, perhatikanlah permasalahan berikut.

\section{Masalah 1}

Andi membeli sebuah semangka kemudian ia memotong semangka tersebut sehingga memiliki permukaan berbentuk lingkaran, seperti Gambar 3 .

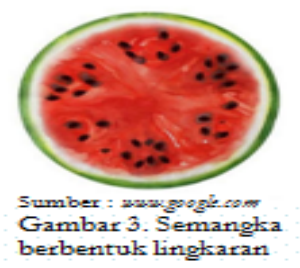

Gambar 1. Masalah konteks

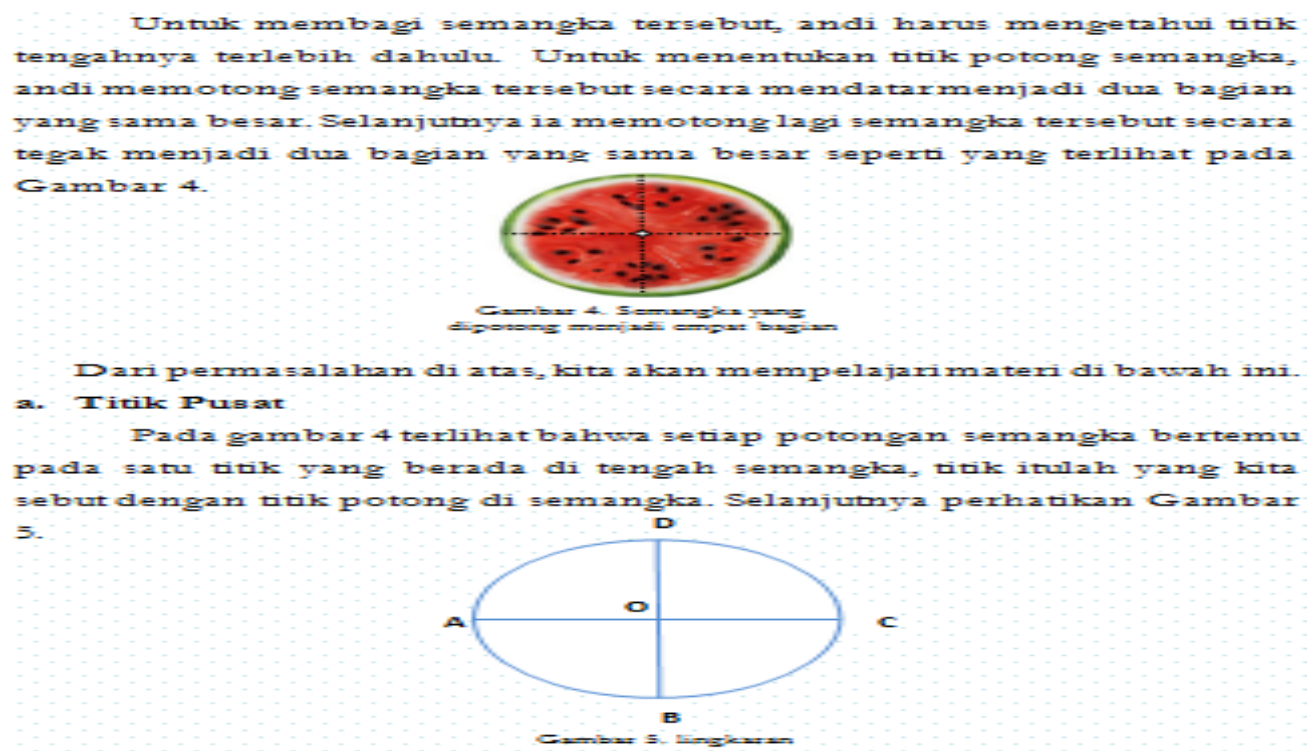

Gambar 2. Pengembangan Model-model 


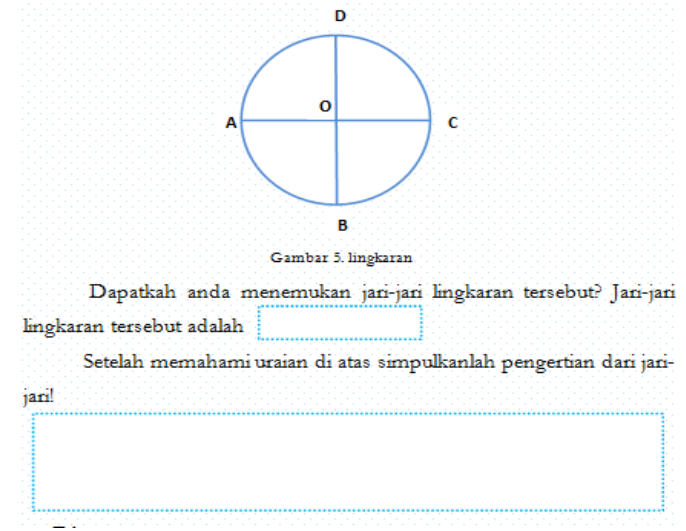

Gambar 3. Sumbangan Pemikiran Para Siswa

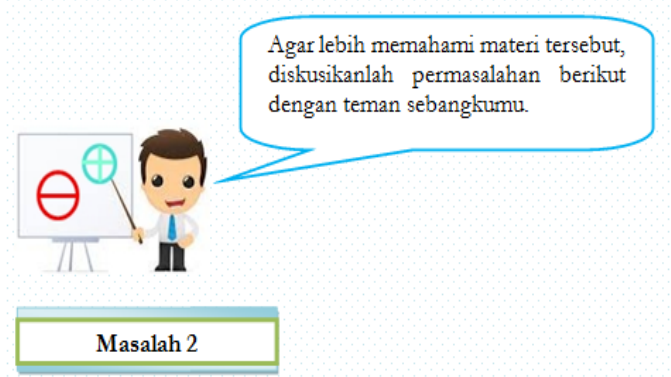

Ibu membeli sebuah kue ulang tahun untuk merayakan hari ulang tatun Dina. Kue itu kemudian dipotong menjadi beberapa bagian seperti yang terlihat pada Gambar 14.

Gambar 4. Interaktif pada Modul

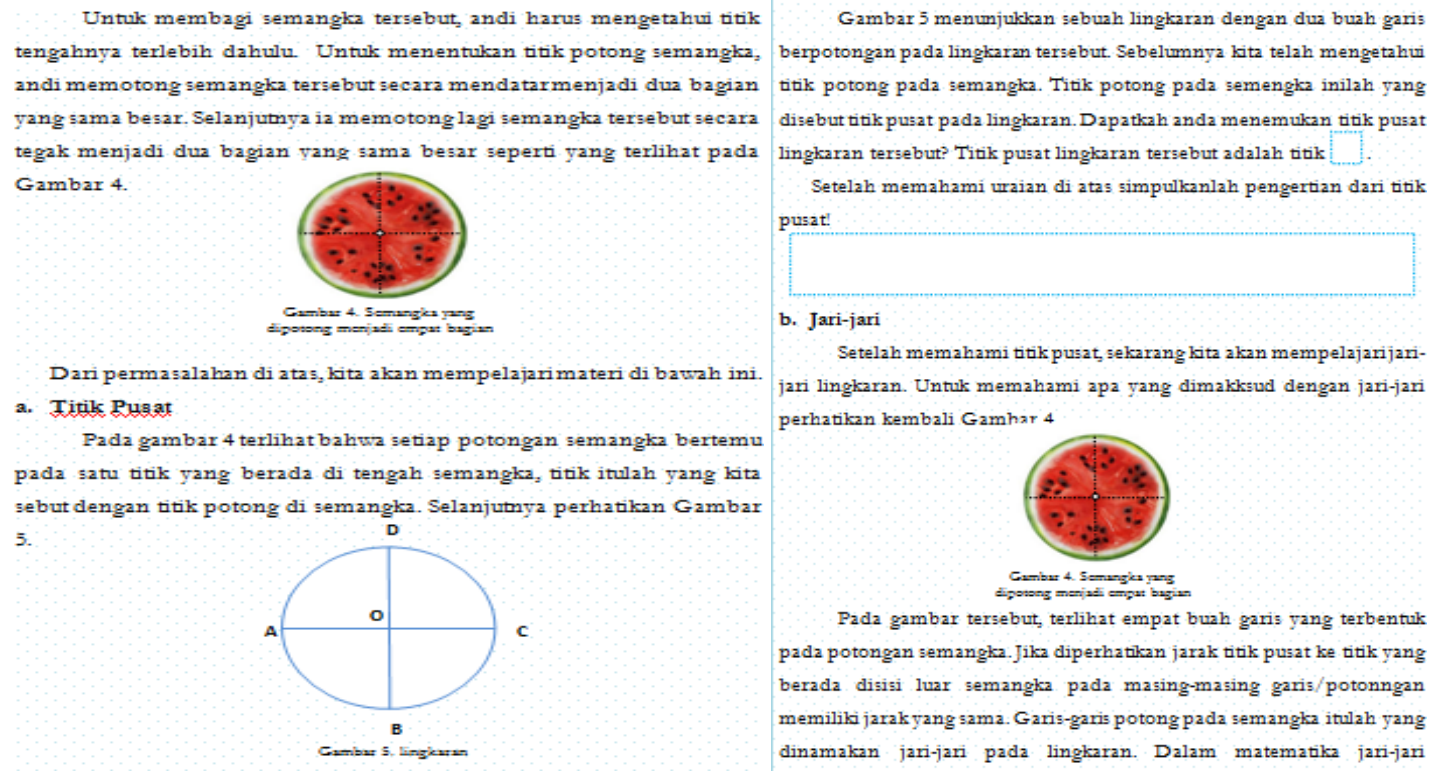

Gambar 5. Jalinan Antar Topik pada Modul

Pada tahap ini dilakukan beberapa evaluasi formatif yaitu, evaluasi diri, tinjuan ahli, uji coba satu-satu dan kelompok kecil. Evaluasi formatif dilakukan untuk melihat praktikalitas modul yang dikembangkan. Apabila modul yang dikembangkan telah praktis, maka bisa dilakukan uji coba lapangan pada tahap selanjutnya.

Evaluasi diri dilakukan untuk mengetahui ketidaksesuaian dalam penyusunan rancangan modul sebelum modul ditinjau oleh ahli. Evaluasi dilakukan dalam bentuk mengisi lembar evaluasi diri. Revisi dilakukan apabila terdapat ketidaksesuaian modul dengan rancangan yang dibuat.

Tinjauan ahli bertujuan untuk melihat validitas modul hasil pengembangan, Tinjauan ahli dilakukan oleh dosen Matematika STKIP PGRI Sumatera Barat. Hasil validasi dapat dilihat pada Gambar 6. Modul dikatakan valid apabila $60<\bar{x} \leq 80$ dan dikatakan sangat valid apabila $\overline{8} 0<\bar{x} \leq 100$. Hasil validasi modul di atas dikategorikan sangat valid dengan rerata $82,38 \%$.validasi para ahli tersebut menunjukkan bahan ajar modul yang dikembangkan sudah memiliki validitas 
dari segi penyajian materi, penyajian, keterbacaan dan bahasa, dan kegrafikan. Artinya materi yang disajikan dalam modul sudah sesuai dengan materi yang harus dipelajari siswa untuk memperoleh capaian pembelajaran matematika, materi yang disajikan pada modul dapat mengarahkan siswa dalam mencapai kompetensi yang ingin dicapai, bahasa yang digunakan dalam modul sudah sesuai dengan kaidah Bahasa Indonesia, dan tampilan modul sudah menarik.

Modul berbasis realistik yang valid diuji praktikalitas. Uji praktikalitas dilakukan oleh dua orang guru mata pelajaran matematika dan enam orang siswa kelas VIII SMPN 1 Sintuk Toboh Gadang. Hasil praktikalitas modul yang dilakukan dapat dilihat pada Gambar 7.

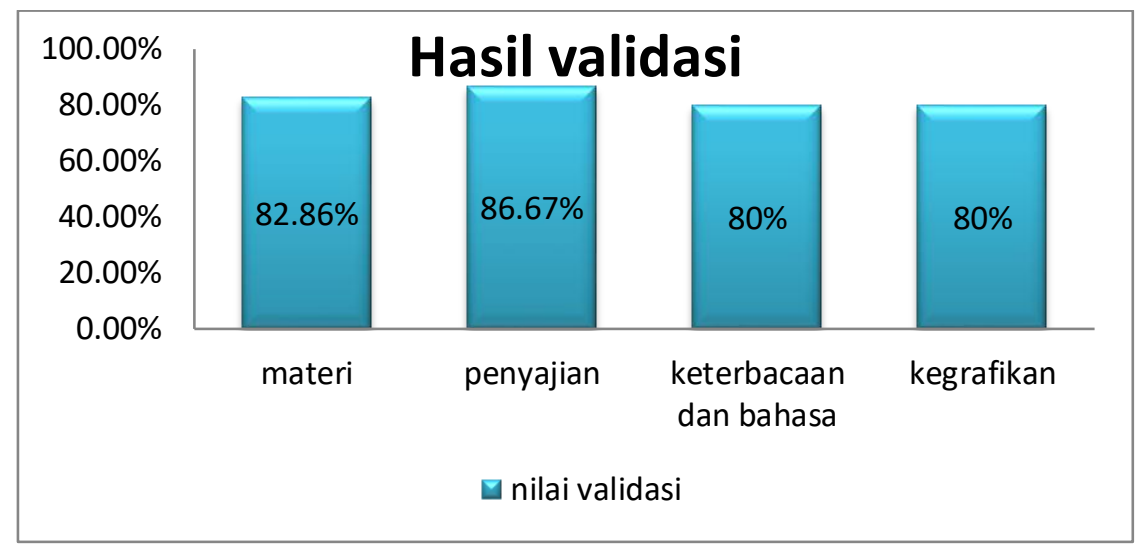

Gambar 6. Diagram hasil validasi modul

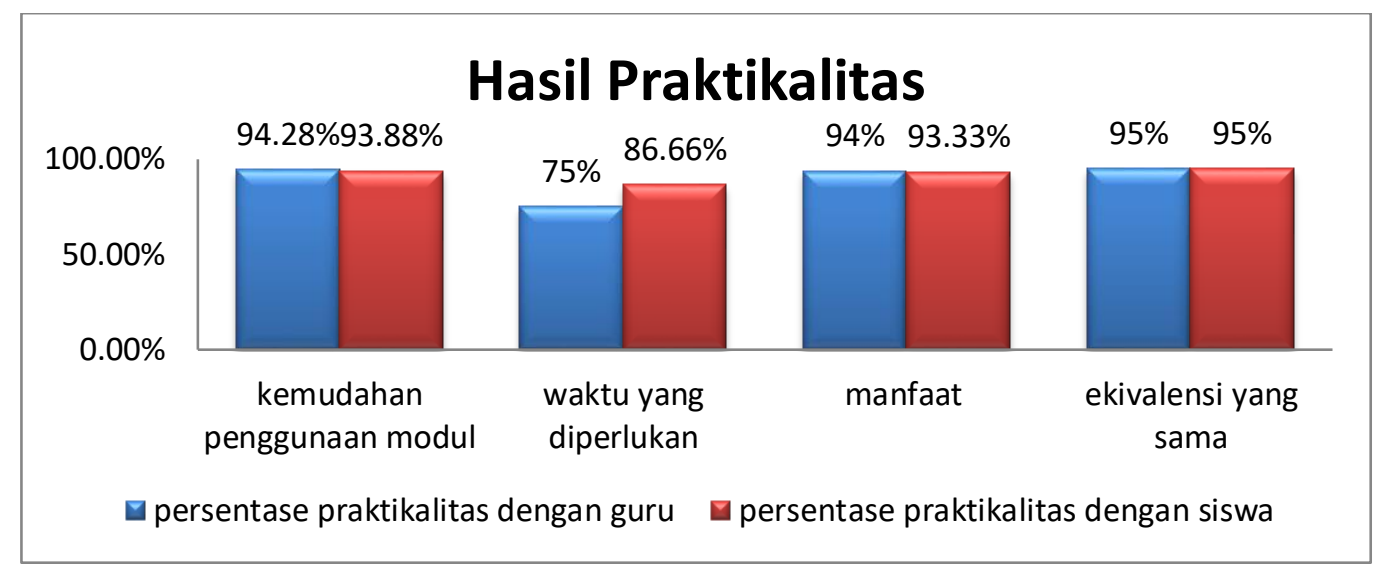

Gambar 7. Grafik hasil praktikalitas modul

Tabel 2. Nilai tes akhir siswa kelas VIII 6

\begin{tabular}{lllll}
\hline \multirow{2}{*}{$\begin{array}{l}\text { Jumlah } \\
\text { Siswa }\end{array}$} & \multicolumn{2}{l}{ Jawaban Benar Siswa $\geq 70 \%$} & \multicolumn{2}{l}{ Jawaban } \\
\cline { 2 - 5 } & Jumlah & Persentase $(\%)$ & Jumlah & Persentase $(\%)$ \\
\hline 20 & 17 & 85 & 3 & 15 \\
\hline
\end{tabular}


Modul dikatakan praktis apabila 60 $<\bar{x} \leq 80$, dan sangat praktis apabila $80<$ $\bar{x} \leq 100$. Berdasarkan Gambar 7 dapat dijelaskan bahwa nilai praktikalitas oleh guru oleh guru dan siswa sangat praktis. Persentase rata-rata praktikalitas modul oleh guru sebesar 89,57\%, sedangkan rata-rata persentase praktikalitas oleh siswa sebesar 92,21\%. Penggunaan modul dinilai bermanfaat bagi siswa dalm memperlajari materi lingkaran. Adanya modul membantu siswa memahami konsep. Siswa berpendapat bahwa dengan adanya modul ini, ia dapat memahami konsep pelajaran dengan baik dan ia dapat belajar dengan gaya belajarnya sendiri. Selain itu, modul dapat dijadikan sebagai sarana untuk membangun pengetahuan pada siswa dan juga memberikan kesempatan kepada siswa untuk mempelajari kembali materi di rumah serta membantu siswa belajar mandiri.

Hasil wawancara tahap praktikalitas dinyatakan bahwa siswa merasa senang belajar dengan menggunakan modul yang dihasilkan. Selain itu, modul yang di-hasilkan juga dapat meningkatkan minat belajar siswa karena modul disajikan dengan permasalahan seharihari siswa. Penggunaan warna dan gambar pada modul menarik perhatian siswa untuk membacanya. Prastowo (2011: 124), menyatakan bahwa gambargambar yang mendukung sangat dibutuhkan dalam pembuatan modul karena menambah daya tarik dan mengurangi kebosanan siswa dalam mempelajarinya.

Aspek efektivitas yang diamati dalam proses pembelajaran dengan menggunakan modul ini adalah hasil belajar siswa. Untuk menilai hasil belajar siswa digunakan tes akhir. Tes akhir ini terdiri dari 2 buah soal uraian. Berikut hasil nilai tes akhir siswa kelas VIII6.

Berdasarkan Tabel 1, terlihat bahwa hasil dari perhitungan ketuntasan belajar siswa terdapat 17 orang siswa yang tuntas dan 3 orang siswa yang tidak tuntas. Ketuntasan belajar (ketuntasan klasikal) dalam kelas tersebut $\geq 78$. Untuk pengembangan modul dikatakan efektif jika minimal $75 \%$ dari jumlah siswa mendapat nilai $\geq 78$. Hasil yang diperoleh persentase siswa yang tuntas berjumlah $85 \%$. Hal ini menunjukkan penggunaan modul berbasis realistik efektif dan memberikan hasil sesuai dengan yang diharapkan. Data hasil keseluruhan lembar validitas modul dan praktikalitas dapat dinyatakan bahwa modul berbasis realistik dihasilkan sudah sangat valid, praktis, dan efektif.

Hal ini juga sejalan dengan penelitian Somayasa (2013) yang menyatakan bahwa pengembangan modul matematika Realistik disertai Asesmen Otentik efektif untuk meningkatkan hasil belajar matematika peserta didik kelas X di SMK Negeri 3 Singaraja, dan juga penelitian yang dilakukan oleh Afreni (2010) dengan judul " Pengembangan Modul berbasis realistik untuk materi himpunan di kelas VII SMP". Penelitian tersebut menghasilkan modul berbasis realistik yang memiliki karakteristik valid dan praktis. Selain itu menurut Usdiana (2009) umumnya siswa merasa senang, tertarik, dan mudah mengerti belajar matematika dengan menggunakan pendekatan realistik, terutama untuk siswa kelompok sedang dan rendah.

\section{PENUTUP}

Berdasarkan hasil pengembangan yang telah dilakukan terhadap pengembangan modul berbasis realistic pada materi lingkaran untuk siswa SMP kelas VIII SMPN 1 Sintuk Toboh Gadang maka diperoleh kesimpulan dihasilkannya modul berbasis realistik pada materi lingkaran untuk kelas VIII SMPN 1 Sintuk Toboh Gadang yang valid, praktis, dan efektif. 


\section{UCAPAN TERIMA KASIH}

Ucapan terimakasih ini disampaikan kepada STKIP PGRI Sumatera Barat, Ketua Program Studi dan sekretaris Pendidikan Matematika STKIP PGRI Sumatera Barat, dan seluruh staf pengajar program studi pendidikan matematika yang telah berikan banyak bantuan dan arahan dalam menyelesaikan artikel ini.

\section{DAFTAR PUSTAKA}

Afreni, T. (2010). Pengembangan Modul berbasis realistik untuk materi himpunan di kelas VII SMP. Skripsi tidak diterbitkan. Padang: STKIP Sumatera Barat.

Hamdani. (2011). Strategi Belajar Mengajar. Bandung: Pustaka Setia.

Miles, Matthew B dan Huberman, Michael, Penerjemah Rohidi, Tjetjep Rohend. (2009). Analisis Data Kualitatif. UI Press. Jakarta.

Plomp. (2013). Educational Design Research : An Introduction, dalam An Introduction to Educational Research. Enschede, Netherland: National Institute for Curriculum Development.

Prastowo, A. (2011). Panduan Kreatif Membuat Bahan Ajar Inovatif. Jogjakarta: DIVA Press.
Somayasa, Wayan,. Natajaya, Nyoman,. Candiasa, Made, (2013). Pengembangan Modul Matematika Realistik disertai Asesmen Otentik Untuk Meningkatkan Hasil Belajar Matematika Peserta Didik Kelas X di SMK Negeri 3 Singaraja. E-Journal Program Pascasarjana Universitas Pendidikan Ganesha Program Studi Penelitian dan Evaluasi Pendidikan. Volume 3.

Suryosubroto. (1983). Sistem Pengajaran Dengan Modul. Bina Aksara. Yogyakarta.

Sudjana, N dan Ahmad R. (2003). Teknologi Pengajaran. Bandung: Sinar Baru.

Trianto. (2009). Mendesain Model Pembelajaran Inovatif-Progresif. Kencana Prenada Group. Jakarta

Usdiana, D, Purniati, T, Yulianti, K, Harningsih, E. (2009). Meningkatkan Kemampuan Berpikir Logis Siswa SMP Melalui Pembelajaran Matematika Realistik. Jurnal Pengajaran MIPA. 13(1). http://journal.fmipa.upi.edu .23-032017.

Walpole, Ronald E., Raymond H Myers. (1995). " Ilmu Peluang dan Statistika Untuk Insinyur dan Ilmuwan. Edisi ke-4, Penerbit ITB, Bandung. 